\title{
PROFIL LANJUT USIA DENGAN DEPRESI YANG TINGGAL DI BALAI PENYANTUNAN LANJUT USIA SENJA CERAH MANADO
}

\author{
Ivone R. Ballo \\ Theresia M. D. Kaunang \\ Herdy Munayang \\ Christoffel Elim
}

\author{
Bagian Psikiatri Fakultas Kedokteran Universitas Sam Ratulangi Manado \\ Email: ivone.ballo@yahoo.com
}

\begin{abstract}
According to the World Health Organisation, depression is still a serious public health problem. Depression is a mood disorder due to a disturbance in human functions related to sad feelings that can occur in every individual, including the elderly. The purpose of this study was to find out the profile of the elderly living in BPLU Senja Cerah (Senior Citizens Home) Manado who suffered from depression. This was an observational study with a cross-sectional design. Samples were all elderly, living in the BPLU Senja Cerah that were willing and able to become respondents, and fulfiled the inclusive and exclusive criteria, including signing informed consents and not suffering from any chronic diseases, such as strokes or cardiac diseases. The study showed that depression was mostly found at the ages of 61-74 years (25\%) and after 1-6 months of staying in BPLU Senja Cerah (21.3\%); the occurence of depression was higher in females (29.8\% of total respondents); and the most frequent type was mild depression (30.4\%). Conclusion: in BPLU Senja Cerah Manado, the respondents who most suffered from depression were in the following categories: the ages of 61-74 years, females, mild types of depression, and having stayed 1-6 months at the center. Keywords: depression, elderly, prevalence of depression
\end{abstract}

\begin{abstract}
Abstrak: World Health Organization (WHO) mengemukakan bahwa depresi masih merupakan masalah kesehatan masyarakat yang serius. Depresi adalah gangguan mood dimana terganggunya fungsi manusia berkaitan dengan alam dan perasaan yang sedih. Gangguan depresi dapat terjadi pada semua individu, termasuk lanjut usia. Penelitian ini bertujuan untuk mengetahui prevalensi gangguan depresi pada lanjut usia yang tinggal di Balai Penyatunan Lanjut Usia (BPLU) Senja Cerah Manado. Penelitian ini menggunakan jenis penelitian observasi dengan deain potong lintang. Sampel penelitian ialah semua lanjut usia yang tinggal di BPLU Senja Cerah Manado yang memenuhi kriteria inklusi dan eksklusi, antara lain bersedia dan bisa menjadi responden serta menandatangani informed consent, dan tidak menderita penyakit kronik seperti stroke atau gangguan jantung. Depresi paling banyak dialami pada kelompok umur 61-74 tahun (25,5\%), telah berdiam di BPLU Senja Cerah selama 1-6 bulan (21,3\%), berjenis kelamin perempuan (29,8\%), dengan tingkat depresi ringan yang terbanyak $(30,4 \%)$. Simpulan: pada lanjut usia yang tinggal di Balai Penyatunan Lanjut Usia (BPLU) Senja Cerah Manado depresi ditemukan terbanyak pada usia 61-74 tahun, jenis kelamin perempuan, jenis depresi ringan, dengan masa tinggal 1-6 bulan.
\end{abstract}

Kata kunci : Depresi, lanjut usia, prevalensi depresi

Depresi merupakan masalah kesehatan masyarakat yang serius. World Health
Organization (WHO) pada tahun 2000 menyatakan bahwa depresi berada pada 
urutan keempat penyakit di dunia sebagai penyebab kacacatan. Diperkirakan pada tahun 2020, depresi akan meningkat dan bisa saja menduduki peringkat kedua dalam masalah kesehatan dunia. ${ }^{1}$

Gangguan depresi merupakan jenis gangguan jiwa yang sering ditemukan, dengan prevalensi seumur hidup sekitar $15 \%$, dengan kemungkinan mencapai $25 \%$ pada perempuan. Rata-rata usia yang rentan mengalami depresi ialah sekitar 40 tahunan. Hampir $50 \%$ awitan terjadi pada usia 20-50 tahun. Gangguan depresi berat dapat timbul pada masa kanak-kanak atau lanjut usia. Data terkini menunjukkan bahwa gangguan depresi berat dapat ditemukan pada usia kurang dari 20 tahun. Hasil survei Perhimpunan Dokter Spesialis Kedokteran Jiwa di Indonesia pada Juni 2004 mengemukakan bahwa sekitar $94 \%$ masyarakat Indonesia mengidap depresi, mulai dari tingkat ringan sampai berat. ${ }^{2,3}$ Terdapat beberapa prediktor penyebab depresi baik faktor genetik maupun non genetik. ${ }^{4}$

Para lanjut usia yaitu berusia lebih dari 60 tahun berisiko rentan terhadap berbagai masalah kesehatan atau penyakit walaupun tampilan dan gejalanya tidak khas, dan biasanya disertai gangguan fungsional. Pada pasien lanjut usia tampilan yang paling umum ialah keluhan somatis, hilang selera makan, dan gangguan pola tidur. Menurut WHO, lanjut usia dibagi menjadi tiga kriteria, yaitu: elderly (64-74 tahun), older (75-90 tahun), dan very old (>90 tahun). ${ }^{5,6}$

Setiap orang pasti ingin memiliki masa tua yang bahagia, tetapi keinginan tidak selalu dapat menjadi kenyataan. Pada kehidupan nyata, banyak sekali para lanjut usia yang mengalami depresi, stress, dan menderita berbagai jenis penyakit. Banyak lanjut usia yang dikirim ke panti jompo dan tidak terurus oleh keluarganya, bahkan ada lanjut usia yang diasingkan dari kehidupan anak cucunya meskipun hidup dalam lingkungan yang sama. Juga terdapat lanjut usia yang masih harus bekerja keras meskipun sudah tua, dan selain hal-hal di atas masih banyak lagi hal lainnya yang menjadi penyebab. Pada para lanjut usia sering muncul berbagai pertanyaan sebagai bentuk kecurigaan dan ketidakpercayaan akan hidup mereka. ${ }^{7,8}$

Data prevalensi depresi pada lanjut usia di Indonesia diperoleh dari ruang rawat darurat geriatri dengan kejadian depresi sebanyak 76,3\%. Data tersebut diperoleh dari studi terhadap populasi Indonesia Timur yang dilakukan di Kabupaten Buru, Maluku pada tahun 2003 dengan subyek sebanyak 401 orang lanjut usia. ${ }^{5}$ Sampai saat ini belum ada penelitian yang dilakukan di Sulawesi Utara tentang depresi pada lanjut usia, lebih khusus lagi di Balai Penyantunan Lanjut Usia Senja Cerah Manado.

\section{DEPRESI}

Phillip L. Rice mengemukakan bahwa depresi adalah gangguan mood kondisi emosional berkepanjangan yang mewarnai seluruh proses mental seseorang. Pada umumnya mood yang secara dominan muncul ialah perasaan tidak berdaya dan kehilangan harapan. Para ahli lainnya menyebutkan bahwa depresi adalah terganggunya fungsi manusia yang berkaitan dengan alam dan perasaan yang sedih dengan gejala penyerta, yang bisa diderita oleh semua golongan usia. Gejala utama yang bisa ditemukan yaitu afek yang menurun, kehilangan minat dan kegembiraan, berkurangnya energi dan menurunnya aktivitas (hipoaktif), perhatian berkurang, harga dan kepercayaan diri berkurang, gagasan tentang rasa bersalah dan tidak berguna, pandangan masa depan yang suram dan pesimistis, gagasan atau perbuatan membahayakan diri atau bunuh diri, kesulitan tidur atau tidur berlebihan, dan nafsu makan berkurang. ${ }^{9-11}$

Prevalensi gangguan depresi pada populasi dunia sebesar $3-8 \%$, dengan $50 \%$ kasus terjadi pada usia produktif yaitu 2050 tahun. World Health Organization menyatakan bahwa gangguan depresi berada pada urutan keempat penyakit di dunia. Kira-kira $10 \%$ pasien berobat ke perawatan primer, sedangkan $15 \%$ dirawat di rumah sakit. Pada anak-anak sekolah didapatkan 
prevalensi kira-kira 2\%, sedangkan pada usia remaja didapatkan prevalensi $5 \%$ dari komunitas yang memiliki gangguan depresi berat. Gangguan depresi berat juga dapat timbul pada masa kanak-kanak atau lanjut usia. Data terkini menunjukkan gangguan depresi berat pada usia kurang dari 20 tahun; hal ini mungkin berhubungan dengan meningkatnya penggunaan alkohol dan penyalahgunaan zat-zat adiktif dalam kelompok usia tersebut. ${ }^{12}$

\section{Etiologi}

Penyebab depresi sangat kompleks, yaitu penyebab eksternal dan penyebab internal, tetapi lebih sering merupakan hasil kombinasi dari keduanya. Berat ringannya depresi tergantung pada kepribadian mental, kematangan individu, progresifitas penyakit fisik, dan tingkat pendidikan. ${ }^{13}$

Hingga saat ini etiologi depresi yang pasti belum diketahui. Terdapat beberapa faktor predisposisi yang telah diketahui berkaitan dengan terjadinya depresi, yaitu antara lain faktor genetik. Faktor ini berperan secara sangat kompleks dalam perkembangan gangguan mood. Pada penelitian mengenai depresi dalam keluarga diperoleh bahwa generasi pertama berpeluang lebih sering dua sampai sepuluh kali mengalami depresi berat. Penelitian yang berhubungan dengan anak kembar mengemukakan bahwa kembar monozigot berpeluang sebesar 50\%, sedangkan kembar dizigot sebesar 10-25\%. Mengenai faktor neurobiologik, adanya perubahan neurotransmiter otak, yaitu antara lain: norepinefrin, serotonin, dopamin, dan juga menurut teori amina biogenik, depresi disebabkan karena defisiensi senyawa monoamin, terutama noradrenalin dan serotonin). Juga perlu dipertimbangkan peran faktor psiko-sosial (peristiwa dalam kehidupan dan stres lingkungan) dan faktor kognitif. ${ }^{13-19}$

\section{Gambaran klinis}

Tanda/gejala gangguan depresi itu adalah tampak sedih/ murung /tak bergairah, pola tidur yang abnormal atau sering terbangun termasuk diselingi kegelisahan dan mimpi buruk sulit konsentrasi pada setiap kegiatan sehari-hari, selalu kuatir, mudah tersinggung dan cemas aktivitas yang tadinya disenangi menjadi makin lama makin dihentikan. ${ }^{20}$

\section{Diagnosis}

Anamnesis merupakan hal yang sangat penting dalam diagnosis depresi dan harus diarahkan pada pencarian terjadinya berbagai perubahan dan terdapatnya lima atau lebih gejala depresi seperti yang dicantumkan pada kriteria diagnosis depresi DSMIV TR. Aloanamnesis dengan keluarga atau informan lain bisa sangat membantu. Gejala depresi pada lanjut usia sering hanya berupa apatis dan penarikan diri dari aktivitas sosial, gangguan memori dan perhatian, terganggunya aktivitas tidur, serta memburuknya kognitif secara nyata. $^{21,22}$

\section{Penatalaksanaan}

Tujuan penatalaksanaan depresi yaitu untuk meringankan gejala-gejala depresi, memperbaiki kualitas hidup, memperbaiki kesehatan secara medis, dan menurunkan mortalitas. $^{13}$

Psikoterapi mencakup terapi keluarga, Cognitive Behavior Therapy (CBT), dan terapi kelompok. ${ }^{13}$

Farmakoterapi yang dapat digunakan antara lain: antidepresan klasik dan generasi kedua. ${ }^{16}$

Antidepresan klasik (trisiklik dan tetrasiklik) mempunyai mekanisme kerja menghambat resorpsi serotonin dan noradrenalin dari sela sinaps di ujung-ujung saraf. Efek samping yaitu efek antikolinergik (mulut kering, penglihatan kabur, konstipasi, retensi urin, takikardia, dan gangguan memori) dan sedasi yang lebih sering terjadi pada pemberian antidepresan trisiklik amina tersier dibandingkan pada pemberian amina sekunder. ${ }^{16}$

Antidepresan generasi kedua, yaitu Selective Serotonin Re-uptake Inhibitor 
(SSRI) dan Noradrenalin and Serotonin Antidepressants (NaSA). Mekanisme kerja SSRI yaitu menghambat resorpsi serotonin. Obat-obat yang tergolong SSRI yaitu sitalopram, escitalopram, fluoksetin, fluvoksamin, paroksetin, dan sertralin. NaSA tidak berkhasiat selektif, dan bekerja menghambat re-uptake dari serotonin dan noradrenalin. Terdapat beberapa indikasi yang menunjukkan bahwa obat-obat golongan ini antara lain venlafaksin, lebih efektif daripada SSRI. ${ }^{17}$

Dalam pemberian farmakoterapi, perlu diperhatikan beberapa faktor penting, yaitu meliputi riwayat pasien terhadap respons obat, riwayat keluarga terhadap respons obat, sub-tipe depresi, riwayat medis pada saat itu, potensi terjadinya interaksi obatobat, profil efek samping obat, dan biaya obat. ${ }^{18}$

\section{DEPRESI PADA LANJUT USIA}

Depresi merupakan penyakit mental yang paling sering pada pasien berusia di atas 60 tahun dan merupakan contoh penyakit yang paling umum dengan tampilan gejala yang tidak spesifik /tidak khas pada populasi lanjut usia. Kondisi multipatologi dengan berbagai penyakit kronik dan polifarmasi semakin meningkatkan kejadian depresi pada lanjut usia. Prevalensi depresi pada lanjut usia kira-kira 6,5\%, sedangkan pada lanjut usia yang menderita penyakit fisik $12-24 \%$, pada rawat jalan $30 \%$, dan pada rawat inap dengan penyakit kronik dan perawatan lama $30-50 \%$. Prevalensi depresi pada lanjut usia lebih tinggi pada ruang perawatan dari pada di lingkungan masyarakat. $^{7,21}$

Terjadinya depresi pada lanjut usia selalu merupakan interaksi dari berbagai faktor dengan penyebab yang kompleks. Beberapa penyebab depresi pada lanjut usia yaitu merasa tidak diperhatikan lagi oleh keluarga sehingga dikirim ke panti jompo; diasingkan dari kehidupan anak cucunya meskipun hidup dalam lingkungan yang sama; masih harus bekerja keras meskipun sudah tua; dan masih banyak lagi hal-hal lainnya yang dapat menyebabkan terjadi- nya depresi pada lanjut usia.

Penanganan depresi pada lanjut usia yaitu dengan melakukan konseling keluarga, terapi kelompok, dan farmakoterapi antidepresan dengan dosis yang sesuai. ${ }^{15,22-24}$

\section{METODE PENELITIAN}

Jenis penelitian menggunakan desain potong lintang, yang merupakan bentuk studi observasional dimana pengukuran variabel dilakukan satu kali pada satu saat. Penelitian dilakukan di Balai Penyantunan Lanjut Usia (BPLU) Senja Cerah Manado selama bulan Desember 2011 sampai Januari 2012. Dalam penelitian ini tidak dilakukan penghitungan sampel. Semua populasi yang memenuhi kriteria diambil sebagai subyek penelitian.

Kriteria inklusi pada pengambilan sampel yaitu para lansia di BPLU Senja Cerah Manado yang bersedia menjadi responden dan mengisi informed consent. Yang menjadi variabel dalam penelitian ini yaitu: usia, jenis kelamin, status pernikahan, riwayat pekerjaan sebelumnya, pendidikan, suku bangsa, lamanya tinggal, dan alasan masuk.

Penelitian ini menggunakan DSM-IV TR, serta kuesioner demografi dan kuesioner Hamilton Depression Rating Scale (HDRS). Setelah mendapatkan informed consent dari responden, dilakukan wawancara dan rating untuk penentuan diagnosis depresi.

\section{HASIL}

Pada penelitian yang dilakukan di Balai Penyantunan Lanjut Usia Senja Cerah Manado mulai bulan Desember 2011 sampai dengan bulan Januari 2012, didapatkan sampel berjumlah 47 orang dari 48 lanjut usia penghuni Balai Penyantunan yang memenuhi kriteria inklusi. Pada saat penggunaan DSM-IV TR, tidak ada responden yang terdiagnosis depresi. Dengan menggunakan HDRS diperoleh hasil sebagai berikut: tidak depresi sebanyak 24 orang $(51 \%)$ dan depresi 23 orang $(48,9 \%)$. 
Dari yang terdiagnosis depresi, ditemukan depresi ringan 17 orang (36\%), depresi sedang 5 orang (12\%), dan depresi berat 1 orang $(2 \%)$. Hasil penelitian ini hampir sama dengan penelitian yang dilakukan di Panti Jompo Penduduk (NH-SDI) di Prancis tahun 2010 dimana dari 99 responden didapatkan 46 orang yang mengalami depresi $(46,5 \%)$. Tingginya prevalensi depresi pada responden kemungkinan berhubungan dengan faktor risiko untuk perkembangan terjadinya depresi pada lanjut usia. ${ }^{25}$

\section{Kejadian depresi berdasarkan usia (Tabel 1)}

Pada penelitian ini didapatkan responden berusia 61-74 tahun sebanyak 19 orang (40,4\%), usia 75-90 tahun sebanyak 26 orang $(55,3 \%)$ dan usia $>90$ tahun sebanyak 2 orang $(4,3 \%)$. Dari 19 responden pada kelompok usia 61-74 tahun, yang mengalami depresi ringan sebanyak 7 orang $(30,4 \%)$, depresi sedang sebanyak 4 orang $(17,4 \%)$, dan depresi berat sebanyak 1 orang $(14,3 \%)$.

\section{Kejadian depresi berdasarkan jenis} kelamin (Tabel 2)

Pada penelitian ini didapatkan dari jumlah total responden 47 orang, terdapat 17 responden laki-laki dan 30 responden perempuan. Dari 17 responden laki-laki, yang mengalami gangguan depresi sebanyak 9 orang $(19,2 \%)$ sedangkan yang tidak mengalami depresi sebanyak 8 orang $(17 \%)$. Pada 30 responden perempuan yang mengalami depresi sebanyak 14 orang $(29,8 \%)$, sedangkan yang tidak mengalami depresi sebanyak 16 orang (34\%).

\section{Kejadian depresi berdasarkan status pernikahan (Tabel 3)}

Pada penelitian ini didapatkan bahwa jumlah responden yang menikah 35 orang $(74,5 \%)$, belum menikah 7 orang $(14,9 \%)$, dan cerai 5 orang $(10,6 \%)$. Hasil terbanyak ialah yang mempunyai status menikah yaitu sebanyak 35 orang, dimana yang mengalami depresi sebanyak 17 orang $(36,2 \%)$ dan yang tidak mengalami depresi sebanyak 18 orang $(38,3 \%)$ (Tabel 3).

\section{Kejadian depresi berdasarkan riwayat pekerjaan sebelumnya (Tabel 4)}

Pada penelitian ini didapatkan bahwa jumlah responden yang berprofesi sebagai Ibu Rumah Tangga yaitu sebanyak 12 orang $(25,5 \%)$, petani 12 orang $(25,5 \%)$, wiraswasta 7 orang $(14,9 \%)$, penjahit 4 orang $(8,5 \%)$, pegawai 3 orang $(6,4 \%)$, pembantu rumah tangga 3 orang $(6,4 \%)$, perawat 2 orang $(4,3 \%)$, guru 1 orang $(2,1 \%)$, sopir 1 orang $(2,1 \%)$, buruh bangunan 1 orang $(2,1 \%)$, koki 1 orang $(2,1 \%)$.

\section{Kejadian depresi berdasarkan pendidik- an (Tabel 5)}

Pada penelitian ini didapatkan bahwa jumlah responden yang berpendidikan SD yaitu sebanyak 34 orang $(72,4 \%)$, SMP 8 orang (17\%), SMA/SMK 4 orang $(8,5 \%)$, sarjana 1 orang $(2,1 \%)$. Jumlah responden depresi terbanyak pada pendidikan SD yaitu sebanyak 15 responden $(31,9 \%)$ dari 23 responden yang mengalami depresi.

\section{Kejadian depresi berdasarkan waktu- lamanya tinggal (Tabel 6)}

Pada penelitian ini didapatkan bahwa jumlah responden terbanyak yang mengalami depresi yaitu yang telah menghuni BPLU Senja Cerah selama 1-6 bulan, sebanyak 10 orang $(21,3 \%)$.

\section{Kejadian depresi berdasarkan alasan masuk (Tabel 7)}

Pada penelitian ini didapatkan bahwa jumlah responden terbanyak dengan alasan masuk BPLU Senja Cerah yaitu atas kemauan sendiri, sebanyak 32 orang $(68,1 \%)$. 
Tabel 1. Distribusi berdasarkan usia

\begin{tabular}{|c|c|c|c|c|c|c|c|c|c|c|c|}
\hline \multirow{3}{*}{$\begin{array}{c}\text { Usia } \\
\text { (tahun) }\end{array}$} & \multirow{3}{*}{$\mathbf{N}$} & \multicolumn{2}{|c|}{ Tidak } & \multicolumn{2}{|c|}{ Depresi } & \multicolumn{6}{|c|}{$\begin{array}{l}\text { Tingkat Depresi } \\
\end{array}$} \\
\hline & & \multirow{2}{*}{$\mathbf{N}$} & \multirow{2}{*}{$\%$} & \multirow{2}{*}{$\mathbf{n}$} & \multirow{2}{*}{$\%$} & \multicolumn{2}{|c|}{ Ringan } & \multicolumn{2}{|c|}{ Sedang } & \multicolumn{2}{|c|}{ Berat } \\
\hline & & & & & & $\mathbf{N}$ & $\%$ & $\mathbf{N}$ & $\%$ & $\mathbf{N}$ & $\%$ \\
\hline $61-74$ & 19 & 8 & 17 & 12 & 25,5 & 7 & $\overline{30,4}$ & 4 & $\overline{17,4}$ & 1 & $\overline{4,3}$ \\
\hline $75-90$ & 26 & 14 & 29,8 & 11 & 23,4 & 10 & 43,5 & 1 & 4,3 & 0 & 0 \\
\hline$>90$ & 2 & 2 & 4,3 & 0 & 0 & 0 & 0 & 0 & 0 & 0 & 0 \\
\hline Total & 47 & 24 & $\overline{51,1}$ & 23 & 48,9 & 17 & $\overline{73,9}$ & 5 & 21,7 & $\overline{1}$ & $\overline{4,3}$ \\
\hline
\end{tabular}

Tabel 2. Distribusi berdasarkan jenis kelamin

\begin{tabular}{|c|c|c|c|c|c|c|c|c|c|c|c|}
\hline \multirow{3}{*}{ Jenis Kelamin } & \multirow{3}{*}{$\mathbf{n}$} & \multicolumn{2}{|c|}{ Tidak } & \multicolumn{2}{|c|}{ Depresi } & \multicolumn{6}{|c|}{$\begin{array}{c}\text { Tingkat Depresi } \\
\end{array}$} \\
\hline & & \multirow{2}{*}{$\mathbf{N}$} & \multirow{2}{*}{$\%$} & \multirow{2}{*}{$\mathbf{n}$} & \multirow{2}{*}{$\%$} & \multicolumn{2}{|c|}{ Ringan } & \multicolumn{2}{|c|}{ Sedang } & \multicolumn{2}{|c|}{ Berat } \\
\hline & & & & & & $\mathbf{n}$ & $\%$ & $\mathbf{N}$ & $\%$ & $\mathbf{N}$ & $\%$ \\
\hline Laki-laki & 17 & 8 & 17 & 9 & 19,2 & 7 & 30,4 & 2 & 8,7 & 0 & 0 \\
\hline Perempuan & 30 & 16 & 34 & 14 & 29,8 & 10 & 43,5 & 3 & 13 & 1 & 4,4 \\
\hline Total & 47 & 24 & 51 & 23 & 49 & 17 & 73,9 & 5 & 21,7 & 1 & 4,4 \\
\hline
\end{tabular}

Tabel 3. Distribusi berdasarkan status pernikahan

\begin{tabular}{|c|c|c|c|c|c|c|c|c|c|c|c|}
\hline \multirow{3}{*}{$\begin{array}{c}\text { Status } \\
\text { Pernikahan }\end{array}$} & \multirow{3}{*}{$\mathbf{n}$} & \multicolumn{2}{|c|}{ Tidak } & \multicolumn{2}{|c|}{ Depresi } & \multicolumn{6}{|c|}{ Tingkat Depresi } \\
\hline & & \multirow{2}{*}{$\mathbf{n}$} & \multirow{2}{*}{$\%$} & \multirow{2}{*}{$\mathbf{n}$} & \multirow{2}{*}{$\%$} & \multicolumn{2}{|c|}{ Ringan } & \multicolumn{2}{|c|}{ Sedang } & \multicolumn{2}{|c|}{ Berat } \\
\hline & & & & & & $\bar{n}$ & $\%$ & $\mathbf{N}$ & $\%$ & $\mathbf{N}$ & $\%$ \\
\hline Menikah & 35 & 18 & 38,3 & 17 & 36,2 & 14 & $\overline{60,9}$ & 3 & $\overline{13,1}$ & 0 & $\overline{0}$ \\
\hline Belum menikah & 7 & 4 & 8,5 & 3 & 6,4 & 3 & 13 & 0 & 0 & 0 & 0 \\
\hline Cerai & 5 & 2 & 4,2 & 3 & 6,4 & 0 & 0 & 2 & 8,7 & 1 & 4,3 \\
\hline Total & 47 & 24 & 51 & 23 & 49 & 17 & $\overline{73,9}$ & 5 & 21,8 & 1 & $\overline{4,3}$ \\
\hline
\end{tabular}

Tabel 4. Distribusi berdasarkan riwayat pekerjaan

\begin{tabular}{|c|c|c|c|c|c|c|c|c|c|c|c|}
\hline \multirow{3}{*}{$\begin{array}{l}\text { Riwayat } \\
\text { Pekerjaan }\end{array}$} & \multirow{3}{*}{$\mathbf{N}$} & \multicolumn{2}{|c|}{ Tidak } & \multicolumn{2}{|c|}{ Depresi } & \multicolumn{6}{|c|}{ Tingkat Depresi } \\
\hline & & \multirow{2}{*}{$\mathbf{n}$} & \multirow{2}{*}{$\%$} & \multirow{2}{*}{$\mathbf{n}$} & \multirow{2}{*}{$\%$} & \multicolumn{2}{|c|}{ Ringan } & \multicolumn{2}{|c|}{ Sedang } & \multicolumn{2}{|c|}{ Berat } \\
\hline & & & & & & $\mathbf{n}$ & $\%$ & $\mathbf{n}$ & $\%$ & $\mathbf{n}$ & $\%$ \\
\hline IRT & 12 & 10 & 21 & 2 & 4,3 & 1 & 4 & 0 & 0 & 1 & 4 \\
\hline Petani & 12 & 5 & 10 & 7 & 15 & 5 & 22 & 2 & 9 & 0 & 0 \\
\hline Wiraswasta & 7 & 2 & 4,3 & 5 & 11 & 3 & 13 & 2 & 9 & 0 & 0 \\
\hline Penjahit & 4 & 3 & 7 & 1 & 2 & 1 & 4 & 0 & 0 & 0 & 0 \\
\hline Pegawai & 3 & 0 & 0 & 3 & 7 & 2 & 9 & 1 & 4 & 0 & 0 \\
\hline Pembantu RT & 3 & 1 & 2 & 2 & 4,3 & 2 & 9 & 0 & 0 & 0 & 0 \\
\hline Perawat & 2 & 1 & 2 & 1 & 2 & 1 & 4 & 0 & 0 & 0 & 0 \\
\hline Guru & 1 & 0 & 0 & 1 & 2 & 1 & 4 & 0 & 0 & 0 & 0 \\
\hline Sopir & 1 & 1 & 2 & 0 & 0 & 0 & 0 & 0 & 0 & 0 & 0 \\
\hline Buruh & 1 & 1 & 2 & 0 & 0 & 0 & 0 & 0 & 0 & 0 & 0 \\
\hline Koki & 1 & 0 & 0 & 1 & 2 & 1 & 4 & 0 & 0 & 0 & 0 \\
\hline Total & 47 & 24 & 50,3 & 23 & 49,6 & 17 & 73 & 5 & 22 & 1 & 4 \\
\hline
\end{tabular}


Tabel 5. Distribusi berdasarkan pendidikan

\begin{tabular}{|c|c|c|c|c|c|c|c|c|c|c|c|}
\hline \multirow{3}{*}{ Pendidikan } & \multirow{3}{*}{$\mathbf{N}$} & \multicolumn{2}{|c|}{ Tidak } & \multicolumn{2}{|c|}{ Depresi } & \multicolumn{6}{|c|}{$\begin{array}{l}\text { Tingkat Depresi } \\
\end{array}$} \\
\hline & & \multirow[t]{2}{*}{$\mathbf{n}$} & \multirow[t]{2}{*}{$\%$} & \multirow[t]{2}{*}{$\mathbf{n}$} & \multirow[t]{2}{*}{$\%$} & \multicolumn{2}{|c|}{ Ringan } & \multicolumn{2}{|c|}{ Sedang } & \multicolumn{2}{|c|}{ Berat } \\
\hline & & & & & & $\mathbf{n}$ & $\%$ & $\mathbf{N}$ & $\%$ & $\underline{\mathbf{n}}$ & $\%$ \\
\hline SD & 34 & 19 & 40,4 & 15 & 31,9 & 11 & 47,8 & 3 & 13 & 1 & $\overline{4,4}$ \\
\hline SMP & 8 & 3 & 6,4 & 5 & 10,6 & 3 & 13 & 2 & 8,7 & 0 & 0 \\
\hline SMA/SMK & 4 & 2 & 4,3 & 2 & 4,3 & 2 & 8,7 & 0 & 0 & 0 & 0 \\
\hline Sarjana & 1 & 0 & 0 & 1 & 2,1 & 1 & 4,4 & 0 & 0 & 0 & 0 \\
\hline Total & 47 & 24 & 51,1 & 23 & 48,9 & 17 & 73,9 & 5 & 21,7 & 1 & 4,4 \\
\hline
\end{tabular}

Tabel 6. Distribusi berdasarkan waktu-lamanya tinggal

\begin{tabular}{|c|c|c|c|c|c|c|c|c|c|c|c|}
\hline \multirow{3}{*}{ Waktu } & \multirow{3}{*}{$\mathbf{N}$} & \multicolumn{2}{|c|}{ Tidak } & \multicolumn{2}{|c|}{ Depresi } & \multicolumn{6}{|c|}{ Tingkat Depresi } \\
\hline & & \multirow{2}{*}{$\mathbf{N}$} & \multirow{2}{*}{$\%$} & \multirow{2}{*}{$\mathbf{n}$} & \multirow{2}{*}{$\%$} & \multicolumn{2}{|c|}{ Ringan } & \multicolumn{2}{|c|}{ Sedang } & \multicolumn{2}{|c|}{ Berat } \\
\hline & & & & & & $\mathbf{n}$ & $\%$ & $\mathbf{n}$ & $\%$ & $\mathbf{n}$ & $\%$ \\
\hline 1- 6 bulan & 11 & 1 & 2,1 & 10 & 21,3 & 7 & 31 & 3 & 13 & $\overline{0}$ & 0 \\
\hline 1- 5 tahun & 16 & 9 & 19,1 & 7 & 14,9 & 5 & 22 & 1 & 4 & 1 & 4 \\
\hline $6-10$ tahun & 9 & 5 & 10,6 & 4 & 8,5 & 3 & 13 & 1 & 4 & 0 & 0 \\
\hline $11-20$ tahun & 8 & 6 & 12,8 & 2 & 4,3 & 2 & 9 & 0 & 0 & 0 & 0 \\
\hline $25-35$ tahun & 3 & 3 & 6,4 & 0 & 0 & 0 & 0 & 0 & 0 & 0 & 0 \\
\hline Total & 47 & 24 & 51 & 23 & 49 & 17 & 75 & 5 & 21 & 1 & 4 \\
\hline
\end{tabular}

Tabel 7. Distribusi berdasarkan alasan masuk

\begin{tabular}{|c|c|c|c|c|c|c|c|c|c|c|c|}
\hline \multirow{3}{*}{ Alasan masuk } & \multirow{3}{*}{$\mathbf{N}$} & \multicolumn{2}{|c|}{ Tidak } & \multicolumn{2}{|c|}{ Depresi } & \multicolumn{6}{|c|}{ Tingkat Depresi } \\
\hline & & \multirow{2}{*}{$\mathbf{N}$} & \multirow{2}{*}{$\%$} & \multirow{2}{*}{$\mathbf{n}$} & \multirow{2}{*}{$\%$} & \multicolumn{2}{|c|}{ Ringan } & \multicolumn{2}{|c|}{ Sedang } & \multicolumn{2}{|c|}{ Berat } \\
\hline & & & & & & $\mathbf{n}$ & $\%$ & $\mathbf{n}$ & $\%$ & $\mathbf{n}$ & $\%$ \\
\hline Kemauan & 32 & 22 & 46,8 & 10 & 21,3 & 8 & $\overline{34,8}$ & 2 & $\overline{8,7}$ & $\overline{0}$ & 0 \\
\hline Dibawa keluarga & 8 & 0 & 0 & 8 & 17 & 5 & 21,7 & 2 & 8,7 & 1 & 4,3 \\
\hline Tidak punya & 7 & 2 & 4,3 & 5 & 10,6 & 4 & 17,4 & 1 & 4,3 & 0 & 0 \\
\hline Total & 47 & 24 & $\overline{51,1}$ & 23 & $\overline{48,9}$ & 17 & $\overline{73,9}$ & 5 & 21 , & 1 & 4,3 \\
\hline
\end{tabular}

\section{BAHASAN}

Dari penelitian-penelitian yang telah dilakukan didapatkan penyebab tersering terjadinya kematian pada pasien dengan gangguan depresi berusia lanjut ialah karena kondisi kardiovaskular berupa stroke atau infark miokard, sedangkan keganasan merupakan penyebab kedua. ${ }^{26}$

Berdasarkan usia, jumlah responden yang mengalami depresi lebih besar terjadi pada kelompok usia 61-74 tahun (elderly) daripada kelompok usia > 90 tahun (very old). Berdasarkan jenis kelamin, didapatkan angka depresi pada perempuan lebih tinggi dari pada laki-laki. Dari acuan pus- taka diperoleh bahwa depresi lebih sering terjadi pada perempuan. Diduga bahwa perempuan lebih sering mencari pengobatan sehingga depresi sering terdiagnosis. Menurut teori psikososial, tingginya angka depresi pada perempuan disebabkan karena terdapatnya berbagai peran yang harus disandang yaitu sebagai pengelola rumah tangga, pekerja, istri, dan sekaligus ibu; kesemuanya ini merupakan stressor yang berperan terhadap meningkatnya kejadian depresi. ${ }^{26,27}$

Berdasarkan pekerjaan, jumlah responden yang depresi lebih besar terjadi pada kelompok ibu rumah tangga dan petani. 
Hasil penelitian ini sesuai dengan penelitian Safitri (2009) yang diadakan di Yogyakarta pada ibu-ibu rumah tangga. Safitri mendapatkan bahwa para wanita khususnya ibu rumah tangga, mudah mengalami depresi oleh karena banyaknya masalah yang dialami dalam kehidupan berumah tangga, terutama yang berhubungan dengan perilaku suami, dan juga mengurus anakanak. $^{28}$

Hasil penelitian ini menyatakan bahwa berdasarkan lamanya tinggal di BPLU Senja Cerah Manado, jumlah responden yang depresi terbanyak yaitu setelah 1-6 bulan menjadi penghuni BPLU. Hal ini disebabkan karena para responden belum dapat beradaptasi dengan lingkungan yang baru.

\section{SIMPULAN}

Berdasarkan hasil penelitian maka disimpulkan bahwa pada lanjut usia yang menghuni Balai Penyatunan Lanjut Usia (BPLU) Senja Cerah Manado depresi ditemukan terbanyak pada usia 61-74 tahun, jenis kelamin perempuan, jenis depresi ringan, dengan masa tinggal 1-6 bulan.

\section{DAFTAR PUSTAKA}

1. World Health Organization. Depression Disorders Management [homepage on the Internet]. c2011 [updated 2011 Nov; cited 2011 Nov 15]. Available from: URL: http://www. who.int/mental_health/management/ depression/definition/en/

2. Amir N. Depresi: Aspek Neurologi, Diagnosis dan Tatalaksana. Jakarta: Fakultas Kedokteran Universitas Indonesia, 2005; p.1-21.

3. Cobelt D. Depresi: Emosi yang Mematikan. Jakarta: Immanuel Publishing House, 2004; p.17-27.

4. Darmojo RB, Martono HH. Buku Ajar Geriatri (Edisi Kedua). Jakarta: Balai Penerbit FKUI, 2000.

5. Soejono CH, Setiati S, Wiwie M. Pedoman Pengelolaan Kesehatan Pasien Geriatri (Edisi Kesatu).
Jakarta: Pusat Informasi \& Penerbitan Bagian Ilmu Penyakit Dalam FKUI, 2004.

6. Goodnict PJ, Hernandez M. Expert Opinion on Pharmaco-therapy: Treatment of Depression in Comorbid Medical Illnes, NewYork: Ashley Publ Ltd, 2000.

7. Burkhart, Stilling K. Diagnosis of depression in the elderly patient. Philadelphia: Lippincott Williams \& Wilkins, 2000.

8. Depression. The British Psychological Society \& The Royal College of Psychiatrists [serial online]. 2011 [cited 2011 Nov 10] Vol 28. Available from: URL: http://www. ncbi.nlm.nih.gov/pubmedhealth/PM H0015794/\#ch3.s4

9. Maramis WF. Depresi. Catatan Ilmu Kedokteran Jiwa (Cetakan Ketujuh). Surabaya: Airlangga University Press, 2004.

10. Wiwie SM, Nasrun S. Pengelolaan depresi pada usia lanjut. Dalam: Soejono CZ, Setiawati S, Wiwie SM, Silaswati S, editors. In: Pedoman pengelolaan kesehatan pasien geriatri (Edisi Kesatu). Jakarta: Pusat Pengembangan dan Penerbitan Bag IPD FKUI, 1999; p.60-67.

11. Iskandar Y. Prevensi dan Terapi Penyakit Depresi. MKI. 1996;20:2933.

12. Kaplan HI, Saddock BJ. Gangguan mood. Dalam: Sinopsis Psikiatri. Jilid 1 (Edisi Ketujuh). Jakarta: Binarupa Aksara (Bahasa Indonesia), 2010.

13. Kaplan HI, Sadock BJ. Depresi. Dalam: Ilmu Kedokteran Jiwa Darurat (Cetakan Kesatu). Jakarta: Widya Medika, 1998.

14. Kaplan HI, Sadock BJ, Grebth JA. Gangguan Mood. Sinopsis Psikiatri. Terjemahan (Edisi Ketujuh). Jakarta: Binarupa Aksara, 1997.

15. Ismail RI, Siste K. Buku Ajar Psikiatri. Jakarta: Balai Penerbit Fakultas Kedokteran Universitas Indonesia, 2010. 
16. Sadock B, Sadock V. Mood Disorders. Comprehensive Textbook of Psychiatry (Eight Edition). Washington: American Psychiatric Association, 2000.

17. Sunandar EY, Andrajati R. ISO Farmakoterapi Cetakan I. Jakarta: PT. ISFI Penerbitan, 2008.

18. Miller RA. The biology of aging and longevity. In: Hazard WR, Blass JP, Ettinger WH (editors). Principle of geriatric medicine and gerontology. New York: McGraw-Hill, 1999; p.3-19.

19. Renggono MD. Geriatri. Proses menua dan implikasi klinis. In: Sudono AW, Setiyohadi B, Alwi I, Simadibrata MK, Setiati S, editors. Buku Ajar Ilmu Penyakit Dalam. Jakarta: Pusat Penerbitan Ilmu Penyakit Dalam Diponegoro, 2009; p.757-67.

20. Martono HH, Pranaka K. Buku Ajar Boedhi-Darmojo, GERIATRI (edisi keempat). Jakarta: Balai Penerbit Fakultas Kedokteran Universitas Indonesia, 2010.

21. Suhana N. Teori-teori tentang proses menua ditinjau dari aspek biologi dan usaha-usaha penanggulangannya. Simposium Nasional Gerontologi Geriatri [simposium]. 1993, 1639.

22. Setiabudi T. Patogenesis Depresi
Dengan Ilustrasi Pada: IDAJI \& RSJP Jakarta, 2001.

23. Santoso H, Ismail A. Memahami Krisis Usia Lanjut. Jakarta: Gunung Mulia, 2009.

24. Van der Cammen TJM, Rai TGS, Exton-Smith AN. Depression. In: Van der Cammen TJM, Rai TGS, Exton-Smith AN, editors. Manual of geriatric medicine. Edinburgh: Churchill Livingstone, 1999.

25. Prado-Jean A, Couratier P, Amounou L, Be'nissan-Tevi, Nubukpo P, Druet-Cabanac $M$, Cle'ment PJ. Development and validation of an instrument to detect depression in nursing homes $(\mathrm{NH}-$ SDI). International Journal of Geriatric Psychiatry. 2010;2:55-8.

26. Kales HC, Maixner DF, Mellow AM. Cerebrovascular Disease and Late Life Depression. American Journal of Geriatric Psychiatry. 2005;1:91-7.

27. Kandouw A, Kandouw JES, Elvira SD, Ariawan I. Proporsi Gangguan Depresi pada penyalahguna zat yang menjalani rehabilitasi di RS Marzoeki Mahdi. CDK. 2007; 34(3/156):136-142.

28. Safitri. Hubungan antara Kekerasan dalam Rumah Tangga dengan Depresi pada Ibu Rumah Tangga. [Skripsi]. Yogyakarta: Universitas Islam Indonesia, 2009. 